Komunike, Volume XI, No. 1, Juni 2019

\title{
PIDANA MATI MENURUT HUKUM ISLAM DAN HUKUM POSITIF DI INDONESIA
}

\author{
Muhammadiah \\ Jakarta Islamic University Indonesia \\ muhammadiahm@yahoo.co.id
}

\begin{abstract}
Abstrak
Kita semua sadar kematian menanti kita, persoalannya disini adalah kapan dan bagaimana kita dijemput oleh kematian itu sendiri bagi sebagian besar manusia kematian merupakan suatu peristiwa yang sangat menakutkan, namun ada juga dijemput kematian dalam keadaan tenang dan damai. Bagaimana dengan mereka yang kematiannya dipituskan oleh sesama manusia hal ini yang selalu menjadi perbedaan dikalangan masyarakat pada umumnya dan dikalangan para sarjana pada khususnya. Dari tahun ketahun bahkan sampai sekarang pembahasan mengenai pro dan kontra terhadap penjatuhan pidana mati terus menjadi pembahasan yang tidak ada habisnya. Di satu sisi, hukuman mati dianggap akan efektif membuat jera pelaku, namun bagi pihak lain pelaksanaan hukuman mati seperti merampas kewenangan pencipta. Riska Alfiyaa Sarjana Universitas Pancasila tahun angkatan 2004 mengatakan memang belum ada bukti stastisik bahwa kejahatan akan menurun jika hukuman mati diterapkan didalam suatu Negara. Sebaliknya tidak diterapkan juga belum terbukti di suatu Negara kejahatan semakin meningkat.
\end{abstract}

Kata kunci: pidana mati, hukum Islam, hukum positif

\section{A. Latar Belakang}

Kematian adalah kepastian bagi setiap insan. Kematian yang direncanakan seperti dalam pelaksanaan pidana mati, betapapun terpidana itu pernah melakukan kejahatan terhadap sesama, didalam masyarakat, termasuk mencabut nyawa sesama,sempat memberikan dimensi lain. Secara spontan mungkin juga terharu,orang kemudian bertanya, atas dasar hak moral apa kita sesama manusia dengan sadar dan penuh keyakinan, memutuskan, menghentikan kehidupan seseorang. 
Komunike, Volume XI, No. 1, Juni 2019

(Djoko Prakoso dan Nurwachid,1983: mengabaikan itu diancam pidana( R. 10). soesilo, 1979:6).

Pidana mati merupakan suatu Tanggal 14 September 1980, dan pidana yang tua dalam usia, tetapi muda dalam berita. Dalam arti pidana mati sejak dahulu sampai sekarang selalu menjadi perdebatan dikalangan orang-orang yang pro dan kontra dengan adanya pidana mati tersebut.

Terhadap pelaksanaan hukuman mati tersebut, timbul reaksi yang cukup hangat dari berbagai pihak.Ada yang pro dan ada yang kontra terhadap hukuman mati. Melainkan suatu kelompok yang bernama "HATI" (hapus hukuman mati), yang menuntut agar hukum mati dihapuskan dari perundang-undangan yang berlaku di Indonesia dipihak lain muncul kelompok "PAHAM"(pembela tanggal 6 Febuari 1980, merupakan hari yang cukup penting dan mendebarkan bagi rakyat Indonesia karena pada tanggal-tanggal tersebut, tiga orang putra Indonesia masingmasing : Oesin Baftari, Henky Tupanwael dan Kusni Kasdut menjalani eksekusi hukuman mati, berdasarkan hukuman yang berlaku dinegara Indonesia (Kiblat, No. 19 Tahun Ke XXVI, Febuari 11, 1980:32).

Kusni Kasdut 53 tahun, telah menjadi pidana mati ditembak hari rabu dini hari tanggal 6 Febuari 1980.Ia dijatuhkan pidana mati karena kejahatannya melakukan perampokan dan pembunuhan. Pelaksanaan pidana hukuman mati), yang telah mati dilaksanakan setelah permintaan mempertahankan kelakuannya grasinya ditolak (Mahmudi, 1980:1).

hukuman mati di Indonesia (M.Yunan

Baik syara'maupun hukum positif Nasution, 1980:67)

memegang prinsip "Legalitas",tidak

R. Sseosilo mendefinisikan "tindak ada hukuman, selain atas kekuatan pidana" sebagai suatu perbuatan yang aturan pidana dalam nash (Undangdilarang dan diwajibkan undang- undang). Akan tetapi dalam penerapan undang yang apabila dilakukan prinsip tersebut ada beberapa diabaikan maka orang melakukan atau 
Komunike, Volume XI, No. 1, Juni 2019

perbedaan antara syara' dengan hukum positif.

1. Masa penerapan asas legalitas, dimana syariat Islam telah menerapkan asas tersebut sebelum dikenal dan diterapkan oleh hukum positif dua belas abad sebelumnya.

2. Cara penerapan asas legalitas: dalam syariat Islam ada tiga cara dalam menerapkan asas legalitas.

a. Pada jarimah-jarimah yang gawat dan yang sangat mempengaruhi keamanan dan ketentraman masyarakat,yaitu jarimah-jarimah hudud, qisas dan diat, asas legalitas dilaksanakan dengan teliti sekali, dimana tiap-tiap jarimah dan hukumnya dicantumkan satu persatu.

b. Pada jarimah-jarimah yang tidak begitu banyak yaitu jarimahjarimah ta'zir pada umumnya syara' memberi kelonggaran dalam penerapan asas legalitas dari segi hukum, dimana untuk hukum jarimah-jarimah tersebut syara' hanya menyediakan sejumlah hukuman untuk dipilih oleh hakim hukuman yang bagi peristiwa-peristiwa yang dihadapinya.

c. Pada jarimah-jarimah ta'zir yang diancam hukuman karena untuk kemaslahatan umum maka syara' memberi kelonggaran dalam penerapan asas legalitas dari segi penentuan macamnya jarimah, karena syariat hanya mencakupkan dengan membuat suatu nash (ketentuan) yang umum sekali dan yang bisa mencakup setiap perbuatan yang mengganggu kepentingan dan ketentraman masyarakat.

Akan tetapi ada hukum-hukum positif cara penerapan asas legalitas untuk semua jarimah sama, suatu hal yang menyebabkan timbulnya kritikankritikan terhadapnya. Pada mulanya hukum positif memakai cara pertama (dalam syara'), untuk semua jarimah, dan hal ini menyebabkan para anggota juri dan hakim-hakim tidak mau menjatuhkan hukuman berat terhadap jarimah yang tidak gawat dan menyebabkan pula pembebasan 
Komunike, Volume XI, No. 1, Juni 2019

banyak terdakwa dalam berbagai peristiwa pidana.

Oleh karena itu, hukum-hukum positif mengambil cara ke dua (dalamsyara') dengan mempersempit kekuasaan hakim dalam memilih hukuman dan dalam menentukan besarnya. Akan tetapi cara inipun di terapkan secara umum, dan salah satu akibatnya ialah semakin berbahayanya jarimah-jarimah gawat yang terjadi, karena hakim-hakim hanya menjatuhkan hukuman-hukuman ringan atas jarimah-jarimah tersebut yang di mungkinkan oleh kekuatan mereka dalam memilih hukuman.Cara ke dua tersebut sekarang di pakai pada kebanyakan sistem hukum-hukum pidana positif.

Akan tetapi beberapa sistim hukum positif seperti hukum-hukum Jerman dan Denmark mengambil juga cara yang ke tiga (dalam syara') untuk beberapa jarimah teertentu. Sudah tentu cara menentukan asas legalitas dalam syariat Islam lebih teliti, lebih elastis dan lebih dapat menjamin keamanan dan ketentraman masyarakat.
3. Segi penentuan jarimah

Dalam syariat islam nashnash yang menentukan macamnya jarimah bersifat umum dan elastis sekali, sehingga bisa menampung semua peristiwa. Kemudian dalam jarimah-jarimah hudud dan qisas diat keumuman tersebut agak dibatasi.Akan tetapi untuk jarimahjarimah lainya, keumuman tersebut berlaku sepenuhnya.Seperti pada jarimah-jarimah ta'zir biasa untuk hukuman ta'zir karena untuk mewujudkan kemaslahatan umum, nash-nash yang menentukan perbuatan jarimah lebih elastisitasnya, sehingga cukup dengan menyebutkan sifatsifatnya.Oleh karna itu suatu perbuatan tidak mungkin di ketahui sebagai jarimah, kecuali sudah terjadinya. Keumuman dan elastisitasnya, nash-nash tersebut mempunyai pengaruh yang besar terhadap kemampuan syariat islam dalm mengahadapi setiap keadaan dan lingkungan.

Akan tetapi pada hukumhukum positif tiap-tiap jarimah di 
Komunike, Volume XI, No. 1, Juni 2019

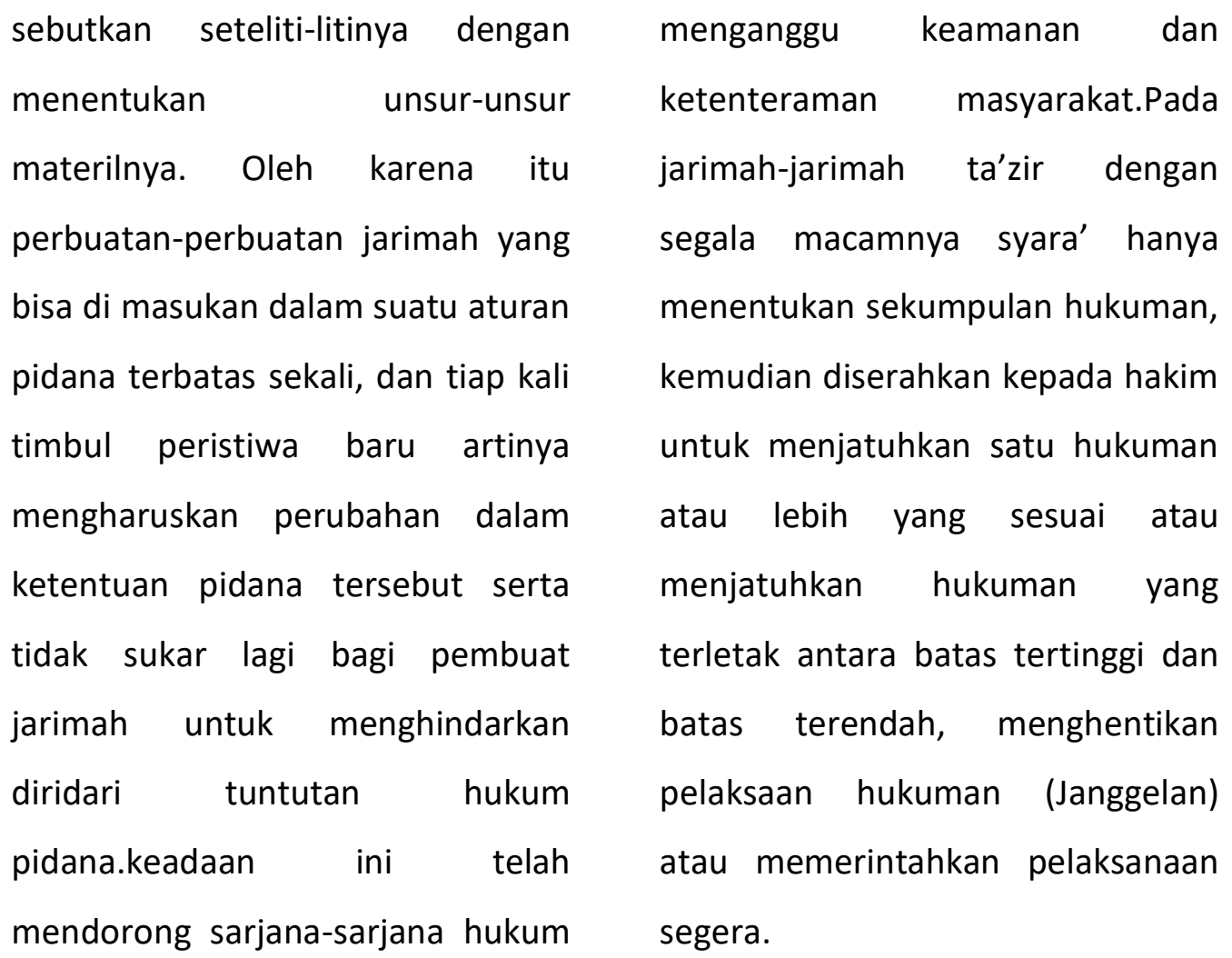

untuk mengatakan bahwa aturan-

Akan tetapi pada hukumaturan pidana harus bersifat mencakup dan elastis,sehingga memungkinkan dia mengambil tindakan terhadap setiap peristiwa.

4. Dari Segi Hukuman

Pada dasarnya syariat menentukan macamnya hukuman dengan jelas, sehingga tidak mungkin bagi hakim untuk menciptakan hukuman dari dirinya sendiri, dan ketentuan hukuman semacam itu berlaku pada jarimahjarimah hudud, dan qisas diyat, yaitu jarimah-jarimah yang sangat hukum positif, untuk tiap-tiap jarimah disediakan satu atau dua macam hukuman yang mempunyai batas tertinggi dan batas terendah.Kemudian hakim bisa menjatuhkan dua hukuman atau satu hukuman yang terletak antara kedua batas tersebut.Hakim juga bisa menunda pelaksanaan hukuman atau merusaknya.Pada beberapa jarimah tertentu hukumhukum fositif menyaratkan hukuman tidak kurang dari batas tertentu, dan juga melarang 
Komunike, Volume XI, No. 1, Juni 2019

dihentikanya

pelaksanaan

hukuman.Pada umumnya hal ini berlaku pada jarimah-jarimah yang sangat berbahaya.

Dari sini nampak pada kita bahwa kekuasaan hakim pada hukum-hukum positif jauh lebih sempit bila dibandingkan dengan kekuasaan hakim pada syariat Islam.Hakim pada hukum positif hanya terbatas pada penjatuhan hukuman yang telah ditentukan oleh hukum positif, apabila hanya terdapat satu hukuman.Giliran hakim hanya baru bisa diperolehnya apabila terdapat dua macam hukuman. Karena hakim tidak boleh menghentikan dilaksanakannya hukumam, maka artinya hakim tidak mempunyai kekuasaan yang cukup untuk bertindak terhadap pembuat sesuai dengan kepentingan umum ( Ahmad Hanafi, 1993:77-80).

Mengikuti perkembangan pro dan kontra hukum mati, maka dalam tesis ini mencoba mengkaji ketentuan-ketentuan dalam hukum Islam danhukum positif di
Indonesia, terutama ayat-ayat AlQur'an, Hadis-hadis dan KUHP yang berhubungan dengan pidana mati dengan cara studi komparatif.

a. Dalam Al-Qur'an

1) Dalam surah Al-Baqarah: 178 yang artinya:

"Hai orang-orang yang beriman, diwajibkan atas kamu qishaash berkenaan dengan orang-orang yang dibunuh; orang merdeka dengan orang merdeka, hamba dengan hamba, dan wanita dengan wanita. Maka Barangsiapa yang mendapat suatu pema'afan dari saudaranya, hendaklah (yang memaafkan) mengikuti dengan cara yang baik, dan hendaklah (yang diberi maaf) membayar (diat) kepada yang memberi ma'af dengan cara yang baik (pula). yang demikian itu adalah suatu keringanan dari Tuhan kamu"

2) Surah Al-Baqarah: 179 yang artinya:

"dan dalam qishaash itu ada(jaminankelangsungan) hidup bagimu, Hai orang-orang yang berakal, supaya kamu bertakwa." 
Komunike, Volume XI, No. 1, Juni 2019

3) Surah al-Maidah : 33 yang artinya:

"Sesungguhnya pembalasan terhadap orang-orang yang memerangi Allah dan RasulNya dan membuat kerusakan di muka bumi, hanyalah mereka dibunuh atau disalib, atau dipotong tangan dan kaki mereka dengan bertimbal balik, atau dibuang dari negeri (tempat kediamannya). yang demikian itu (sebagai) suatu penghinaan untuk mereka didunia, dan di akhirat mereka beroleh siksaan yang besar,"

4) Surah Al-Maidah: 45 yang artinya:

"dan Kami telah tetapkan terhadap mereka di dalamnya (At Taurat) bahwasanya jiwa (dibalas) dengan jiwa, mata dengan mata, hidung dengan hidung, telinga dengan telinga, gigi dengan gigi, dan luka luka (pun) ada kisasnya. Barangsiapayang melepaskan (hak kisas) nya, Maka melepaskan hak itu (menjadi) penebus dosa baginya. Barangsiapa tidak memutuskan perkara menurut apa yang diturunkan Allah, Maka mereka itu adalah orangorang yang zalim"

b. Hadis Nabi Muhammad Saw

1) HR. Al-Bukhari dan Muslim Artinya: Dari ibnu Mas'ud ra berkata: Rasulullah saw, bersabda "tidak dihalalkan darah (membunuh) seorang muslim yang bersaksi bahwa tiada Tuhan selain Allah dab aku adalah utusan Allah, kecuali disebabkan salah satu tiga sebab: seorang yang telah menikah berbuat zina, membunuh orang lain, keluar dari agamanya serta memisahkan diri dari jamaah" (Shahih Muslim, 1988:224)

2) HR. Abu Dawud dan Tirmidzi Artinya: Rasulullah saw bersabda: "barangsiapa yang keluarganya dibunuh, maka ia boleh memilih yang terbaik dari dua pertimbangan, yaitu antara mengambil diyat atau memaafkan". (Ibnu Rusyd, 2007:522 
Komunike, Volume XI, No. 1, Juni 2019

c. Dalam KUHP dan luar KUHP

1) Pasal 104

"Penyerangan (maka) yang dilakukan dengan maksud hendak menghilangkan nyawa presiden atau wakil presiden, atau dengan maksud hendak merampas kemerdekaan mereka itu, atau hendak menjadikan mereka itu tidak cukup memerintah dipidana dengan pidana mati atau penjara seumur hidup atau penjara sementara selama-lamanya dua puluh tahun"( R. Sugandhi, 1980:120).

2) Pasal 340

"Barangsiapa dengan sengaja dan dengan direncanakan lebih dahulu menghilangkan nyawa orang, karena bersalah melakukan pembunuhan berencana, dipidana dengan pidana mati atau penjara seumur hidup atau penjara sementara selama-lamanya dua puluh tahun"

(R. Sugandhi, 1980:359).

3) Undang-Undang Darurat

Nomor 12 Tahun 1951 (LN

NOMOR 78)

"Dalam pasal 1 ayat (1) disebutkan bahwa:

barangsiapa tanpa hak memasukkan ke Indonesia, membuat, menerima, mencoba memperoleh, menyerahkan atau mencoba menyerahkan, menguasai, membawa, mempunyai persediaan padanya atau mempunyai dalam miliknya menyimpan, mengangkut, menyembunyikan,

mempergunakan atau mengeluarkan dari Indonesia sesuatu senjata api, munisi atau sesuatu bahan peledak, dihukum dengan hukuman mati atau hukuman penjara sementara setinggi-tingginya dua puluh tahun

(M. Karyadi:181)

Penulis mengangkat jurnal ini dengan alasan bahwa dari kategori jarimah sebagaimana diuraikan di atas, tanpak bahwa tindak pidana (jarimah) yang sudah dikategorikan sebagai hudud bersikap tetap dan pasti tidak bisa diubah-ubah atau ditawar-tawar lagi karena sudah digolongkan sebagai hak Allah.Sedangkan hukum qisas-diyat dianggap sebagai hak manusia karena qisas bisa diganti dengan diyaat atau bahkan dihapuskan berdasarkan pemaafan pihak korban.Hukuman takzir juga bukan merupakan hak Allah 
Komunike, Volume XI, No. 1, Juni 2019

karena ditentukan oleh
pemegang kebijakan.

\section{B. Pembatasan dan Perumusan Masalah}

Di dalam mengatur masalah pidana Islam menempuh dua macam cara, yaitu:

\section{Menetapkan hukum} berdasarkan nash

Dalam cara yang pertama, Islam tidak memberikan kesempatan kepada penguasa (uli) al-amri) untuk menetapkan hukum yang menyimpang dari ketentuan yang telah ditetapkan dalam AlQur'an dan Al-Sunnah. Hukumanhukuman untuk tindak pidana yang termasuk dalam kelompok yang pertama ini berlaku sepanjang masa dan tidak berubah karena perubahan ruang dan waktu.Bagian yang pertama inilah yang membedakan antara kukum pidana menurut syariat Islam dengan hukum pidana yang berlaku sekarang ini berbagai Negara termasuk Republik Indonesia.
2. Menyerahkan penetapannya kepada penguasa (ulil al-amri)

Dalam cara yang kedua, Islam memberikan kesempatan yang luas kepada penguasa untuk menetapkan macam-macam tindakan pidana dan hukumnya. Al-Qur'an dan As-Sunnah hanya memberikan ketentuan umum, yang penjelasannya diserahkan kepada penguasa. Ketentuan umum tersebut adalah bahwa setiap perbuatan yang merugikan, baik terhadap individu maupun masyarakat, merupakan tindak pidana yang harus dikenakan hukuman.Tindak pidana yang termasuk dalam kelompok ini, oleh para ahli hukum Islam dinamakan jarimah Takzir dan hukumannya pun disebut hukuman takzir.

Dari kedua macam cara penerapan hukum pidana di atas yang menjadi pembatasan masalah adalah yang termasuk jarimah-jarimah hudud dan jarimah qisas. 
Komunike, Volume XI, No. 1, Juni 2019

Berdasarkan pembatasan menurut hukum Islam dan hukum masalah yang telah disebutkan, positif maka masalah yang akan diteliti Sedangkan kegunaan penulis rumuskan sebagai beriku: penelitian ini diharapkan sebagai

a. Dalam hal apa pidana mati diatur oleh hukum Islam dan hukum positif?

berikut:

1. Sebagai bahan informasi kepada mahasiswa, dan masyarakat

b. Pihak-pihak mana atau siapa tentang adanya pidana mati yang sajakah yang diancam dengan diatur dalam hukum Islam dan pidana mati menurut hukum Islam dan hukum positif?

c. Apa hikmah yang terkandung dalam pidana mati menurut hukum Islam dan hukum positif?

\section{Tujuan Dan Kegunaan Penelitian}

Adapun tujuan yang hendak dicapai dengan penulisan jurnal ini adalah:

1. Untuk mengetahui signifikan pidana mati menurut hukum Islam dan hukum positif

2. Untuk mengetahui pihak-pihak apa yang diancam dengan hukum pidana mati menurut hukum Islam dan hukum positif

3. Untuk mengetahui hikmah yang terkandung dalam pidana mati

\section{Kajian Pustaka}

Pada kajian pustaka ini penulis banyak sekali mempelajari atau mengkaji dari kitab-kitab atau bukubuku yang telah ada seperti karya Ibnu Rusyd Bidayatul Mujtahid, karya Sulaiman Rasyid Figh Islami, Ahmad Hanafi asas-asas hukum pidana Islam, Ridwan Limitasi hukum pidana Islam, Bismar Siregar hukumdalam sorotan 
Komunike, Volume XI, No. 1, Juni 2019

perspektif Islam, Abdul Qadir Audah Al-Tasyri' Al-Jina'I Al-Islami, Shahih AlBukhari dan Muslim dan KUHP.

\section{E. Metode Penelitian}

Dalam menyusun jurnal ini, penulis menggunakan metode komparatif yang ditunjang oleh datadata yang diperoleh melalui penelitian kepustakaan (lirary reseach).Penelitian yang dimaksud adalah mempelajari, mengabalisa, membandingkan dan mengkaji sumber-sumber lain yang erat kaitannya dengan masalah yang dibahas. Setelah data terkumpul, kemudian data tersebut akan dibahas dengan cara mengkomparatifkan H.A. Dardiri, 1986).

Dalam usaha mengenal pustaka, patokan-patokan dibawah ini kiranya dapat dijadikan pedoman:

1. Mempelajari hasil apa yang telah atau pernah didapat oleh orang lain dalam bidang penelitian yang bersangkutan

2. Mempelajari metode penelitian apa yang telah dipergunakan, termasuk metode pengambilan contoh, metode pengumpulan data, metode pengolahan data, dan sumber data.

3. Mempelajari faktor-faktor deskriftif dan histories yang ada, yang menjadi latar belakang dari problema yang akan dating.

4. Mempelajari analisis dari problema yang telah dilakukan oleh orang lain.

Secara garis besar, sumber bacaan itu dapat ditemukan dalam sumber bacaan umum, yaitu kepustakaan yang berwujud bukubuku teks, dan ensiklopedia, monografi dan sejenisnya. Generalisasi, dapat ditarik dari laporan hasil penelitian terdahulu yang relevan bagi masalah yang sedang digarap. Hasil-hasil penelitian terdahulu itu pada umumnya dapat ditemukan dalam sumber acuan khusus, yaitu kepustakaan yang berwujud jurnal, bulletin, penelitian tesis, disertasi dan sumber bacaan lain yang memuat laporan hasil penelitian ( S. Margono, 2005). 
Komunike, Volume XI, No. 1, Juni 2019

F. Hasil dan Pembahasan

1. Pengertian Pidana Mati Menurut Hukum Islam

Pidana mati adalah hukuman yang terberat yang dapat dijatuhkan pengadilan yaitu dengan mencabut nyawa seorang sampai mati (Andi Hamzah, 1986:475).Hukum pidana Islam merupakan terjemahan dari kata figh jinayah.Figh jinayah adalah segala ketentuan hukum mengenai tindak pidana atau perbuatan kriminal yang dilakukan oleh orang mukallaf (orang yang dapat dibebani kewajiban), sebagai hasil dari pemahaman atas dalil-dalil hukum yang terperinci dari AlQur'an dan Al-Sunnah (Dede Rosyada, 1992:82).Hukum Islam dalam arti, segala kaidah-kaidah yang mengatur perbuatan manusia serta kasus-kasus yang terjadi di dunia ini (bahkan di akhirat) menurut Islam dapat dikelompokkan dalam dua kelompok besar: pertama, hukum yang bersumberkan Allah SWT dengan peraturan Rasulnya yang disebut "At-Tasyri'ul Ilahi", dan kedua, yang bersumber dari manusia, baik manusia perorangan maupun kelompok, ini disebut "AtTasyri'ul Wadh'i" (Abdul Wahab Khalaf:7)

Dalam hukum pidana Islam dikenal dengan istilah "jarimah". Jarimah adalah melakukan setiap perbuatan yang menyimpang dari kebenaran, keadilan, dan jalan yang lurus (agama) (Muhammad Abu Zahrah:22) Maka jarimah itu adalah melakukan perbuatan haram yang diancam hukuman, atau meninggalkan perbuatan yang diperintahkan yang apabila ditinggalkan mendapat hukuman . banyak pula ulama yang menyebut "Jarimah" ini dengan lafaz "Jinayah", jinayah adalah perbuatan yang dilarang oleh syara' baik mengenai jiwa, harta dan lainnya (M. Abdul Mujieb, 1994:141)Sedangkan menurut (Abdul Qadir Audah, 1994:67) Jinayah adalah nama untuk perbuatan yang diharamkan oleh syara' baik perbuatan itu atas jiwa, 
Komunike, Volume XI, No. 1, Juni 2019

harta atau selain jiwa dan harta.Namun ulama menggunakan jarimah ini untuk perbuatanperbuatan atas tindak pidana "hudud dan qisas".

Kalau dilihat dari segi
hukuman seperti apa yang
dikemukakan oleh Abdul Qadir
Audah yaitu:

a. Jarimah Al-hudud, yaitu tindak pidana yang kadar hukumannya telah ditentukan oleh Allah SWT

b. Jarimah Al-Qishas dan diyat, yaitu tindak pidana yang dikenai sanksi qishas dan diyat. Qishas dan diyat ini adalah hukuman yang ditentukan hukumannya, tapi merupakan hak individuindividu, artinya bahwa hukuman itu ditentukan karena hanya mempunyai satu had (hukuman) yang telah ditentukan. Sebagai hak individu, bila pihak individu yang dirugikan karena tindak pidana ini menghendaki pemaafan, adalah merupakan haknya dan dapat diterima dn dibenarkan secara hukum, sehingga hukuman hadnya itu hilang karena pemaafan itu. Tapi hukuman takzir tetap dikenakan.

c. Jarimah takzir, yaitu perbuatanperbuatan pidana yang hukumnya tidak disyariatkan oleh syara dengan hukuman tertentu. Sebagimana yang dikemukakan oleh Mahmud Syaltut tentang hukuman takzir (Muhammad Syaltut, 1996:299) Dalam kejahatan hudud adalah: Melakukan zina, qadzaf (menuduh melakukan zina, pencurian, mabuk, khirabah (menyamun), dan murtad, albaghy (pemberontakan. Adapun jenis kejahatan qishas adalah pembunuhan, kejahatan athraf dan melukai badan(Sayyid Sabiq:302-426)

\section{Pengertian Pidana Mati Menurut Hukum Positif}

Menurut Suharto RM hukum pidana adalah semua aturan-aturan yang menentukan syarat-syarat akibat hukum itu dan semuanya aturan-aturan untuk mengenakan atau menjatuhi dan menjalankan 
Komunike, Volume XI, No. 1, Juni 2019

pidana tersebut (Suharto RM, dengan mencabut nyawa seorang 2002:3) Sedangkan menurut Yan sampai mati.

Pramadya Puspa hukum pidana

Dalam KUHP terdapat adalah termasuk hukum publik yang delapan kejahatan yang diancam mengancam perbuatan melanggar dengan hukum pidana mati, yaitu: hukum (tindak pidana) dengan pasal 104, 111 ayat 2, 124 bis, 140 pidana atau hukuman (Yan ayat 3,365 ayat 4,368 ayat 2 , dan Pramadya Puspa, 1977:672)Jadi 444. Pidana mati selalu diancam hukum menurut hukum pidana dengan pidana penjara seumur adalah merupakan siksaan atau hidup atau selama dua puluh tahun. penderitaan yang oleh kitab Jika seorang hakim menjatuhkan Undang-undang hukum pidana pidana mati, maka hukuman itu diberikan kepada seorang yang tidak boleh dijalankan sebelum telah melanggar suatu norma presiden diberi kesempatan akan hukum yang ditentukan oleh Undang-undang hukum pidana.

Dan yang dimaksud dengan pidana mati adalah sebagaimana yang disebutkan oleh para pakar:

Menurut Lomrosso dan Garopalo pidana mati merupakan alat mutlak yang harus ada dalam masyarakat untuk melenyapkan individu yang tidak mungkin diperbaiki lagi (Roesla Saleh, 1978:12)Sedangkan menurut (Andi Hamzah, 1977:475) Pidana mati adalah hukum yang terberat yang dapat dijatuhkan pengadilan yaitu memberi grasi (mengubah pidana mati menjadi hukum penjara seumur hidup atau sementara). Hal ini dimaksudkan agar supaya jangan sekali-kali seorang yang tidak bersalah dihukum mati dengan sesuatu kekhilafan hakim, maka hakim yang luar biasa pada pengadilan negeri tidak boleh mengadili kejahatan-kejahatan yang diancam dengan pidana mati.

Menurut pasal 370 RIB, pidana mati tidak boleh dijalankan terhadap seorang gila dan seorang perempuan yang hamil.Dalam hal 
Komunike, Volume XI, No. 1, Juni 2019

pertama melakukan pidana mati ditangguhkan hingga orang gila itu sembuh kembali, dan dalam hal kedua, hingga perempuan yang hamil itu sudah melahirkan. Selain itu, hukuman mati tidak boleh dilakukan dimuka umum, melainkan dengan cara tidak dapat dilihat oleh orang banyak.(C.S.T. Kansil, 2009:4)

Menurut hukum positif kejahatan-kejahatan yang dipidana dengan hukuman mati adalah pertama kejahatan terhadap keamanan Negara, pasal 104 sebagai pasal pertama Bab I Buku II KUHP, kedua pembunuhan dengan berencana, pasal 340 KUHP, ketiga pencurian dan pemerasan yang dilakukan dalam keadaan yang memberatkan sebagai yang disebut dalam pasal 4 dan pasal 356 ayat (4) dan pasal 368 ayat (2) KUHP, keempatpembajakan di laut, dipanti, di pesisir, dan di sungai yang dilakukan dalam keadaan tersebut dalam pasal 444 KUHP, sedang di luar kitab Undang-undang hukum pidana mati yaitu kelima Undang-undang darurat nomor 12 tahun 1951 (LN nomor 78) tentang senjata api, keenam undang-undang nomor II tahun 1963 tentang pemberantasan subversi (gerakan bawah tanah untuk menggulingkan pemerintahan yang sah), ketujuh kejahatan penerbangan dan kejahatan terhadap sarana atau prasarana penerbangan, dan yang kedelapan adalah Undang-undang nomor 1976 tentang narkotika.

\section{Hikmah Pidana Mati}

a. Menurut hukum Islam

Pembuat hukum tidak menyusun ketentuan-ketentuan hukum dari syariat tanpa tujuan apa-apa.Melainkan disana ada tujuan-tujuan tertentu yang luas. Dengan demikian untuk memahami pentingnya suatu ketentuan, perlu mengetahui apa tujuan dari ketentuan itu.

Menurut A. Hanafi, tujuan hukum itu adalah untuk pencegahan dan pengajaran serta pendidikan. Pengertian pencegahan adalah menahan pelaku agar tidak mengulangi perbuatan jarimah atau 
Komunike, Volume XI, No. 1, Juni 2019

agar tidak terus menerus memperbuatnya. Para ahli hukum Islam mengklasifikasi tujuan-tujuan yang luas dari syariat sebagai berikut:

1). Menjamin keamanan

Menjamin keamanan dari kebutuhan-kebutuhan hidup merupakan tujuan pertama dan utama dari syariat.Ini merupakan hal-hal yang penting dalam kehidupan manusia sehingga tidak bisa dipisahkan.Apabila kebutuhan-kebutuhan ini tidak terjamin, maka terjadi kekacauan dan ketidaktertiban dimanamana. Kelima kebutuhan hidup yang primer ini dalam hukum Islam disebut Al-Maqasid AlSyari'ah Al-Khamsah (tujuantujuan Syariah), yaitu memelihara agama, memelihara jwa, memelihara keturunan, memelihara akal pikiran dan memelihata harta.

2). Menjamin keperluan-keperluan

Menjamin keperluan sekunder. Ini menyangkut hal-hal yang penting bagi ketentuan itu dari berbagai fasilitas untuk penduduk dan memudahkan kerja keras dan beban tanggungjawab mereka. Dengan kata lain keperluan-keperluan ini terdiri dari hal-hal yang menyingkirkan kesulitankesulitan dari masyarakat dan membuat hidup mudah bagi mereka.

3). Membuat perbaikan-perbaikan

Tujuan ketiga dari perundang-undanganIslam adalah membuat perbaikanperbaikan, yaitu menjadikan halhal yang dapat menghiasi kehidupan sosial dan menjadikan manusia mampu berbuat dan urusan-urusan hidup secara lebih baik.

b. Menurut hukum positif

Sebelum timbulnya teori terbaru tentang tujuan hukuman, hukum positif telah mengalami fase. Fase-fase tersebut adalah sebagai berikut:

1). Fase balasan perseorangan

Pada fase ini, hukuman berada ditangan perseorangan 
Komunike, Volume XI, No. 1, Juni 2019

yang bertindak atas dasar
perasaan hendak menjaga diri
mereka dari penyerangan dan
dasar naluri hendak membalas
yang menyerangnya.
Fase balasan tuhan dan balasan
mum

Adapun yang dimaksud balasan Tuhan adalah bahwa orang yang berbuat harus menebus kesalahannya sedangkan balasan umum adalah agar orang yang berbuat merasa jera dan orang lain pun tidak berani meniru perbuatannya. Hukuman yang didasarkan atas balasan ini tidak lepas dari unsurunsur negatif seperti berlebihan dan melampaui batas dalam memberikan hukuman.

3). Fase kemanusiaan

Pada fase kemanusiaan, prinsip-prinsip keadilan dan kasih sayang dalam mendidik dan memperbaiki diri orang yang berbuat telah mulai dipakai.Bahkan memberi pelajaran dan mengusahakan kebaikan terhadap diri pelaku merupakan tujuan utama.

\section{G. kesimpulan}

Pidana mati dalam hukum Islam dan hukum positif merupakan hukuman terberat dari keseluruhan hukuman yang dijatuhkan kepada pelaku kejahatan, sebab ia menyangkut jiwa manusia.

1. Pidana mati diatur oleh hukum Islam dan hukum positif dinamakan unsur formil, melakukan perbuatan yang diancam dengan pidana, baik dengan melakukan perbuatan atau tidak melakukan perbuatan, dalam hukum positif dikenal dengan unsur materiil dan hendaknya pelaku pidana kejahatan itu mukallaf atau bertanggung jawab atas tindak pidana yang dilakukannya, dalam hukum positif disebut dengan unsur materiil.

2. Hukum pidana mati menurut hukum Islam adalah pembunuhan dengan cara sengaja menggunakan alat yang mematikan pada kebiasaannya, perzinaan, perampokan, pemberontakan, dan 
Komunike, Volume XI, No. 1, Juni 2019

murtad sedangkan menurut hukum positif adalah kejahatan yang dilakukan kepada keamanan Negara, pembunuhan yang dilakukan dengan berencana, pencurian dan pemerasan yang dilakukan dalam keadaan yang memberatkan sebagai yang disebut dalam pasal 365 ayat (4) dan pasal 368 ayat (2) KUHP, pembajakan dilaut, di pantai, di pesisir dan di sungai yang dilakukan dalam seperti tersebut dalam pasal 444 KUHP, Undang-undang darurat Nomor 12 Tahun 1951 (LN No.78) tentang senjata api, Undang-undang No 11 PNPS 1963 tentang pemberantasan kegiatan subversi, kejahatan penerbangan dan kejahatan terhadap sarana atau prasarana penerbangan, dan Undang-undang No.9 Tahun 1976 tentang narkotika.

3. Hikmah yang terkandung dalam pidana mati menurut hukum Islam adalah pencegahan, dan pengajaran serta pendidikan agar tujuan hukum itu bisa tercapai, sedangkan menurut hukum positif adalah supaya yang melakukan tindak pidana dapat merasakan pembalasan atas perbuatan yang dilakukannya dan jera serta orang lain tidak berani melakukannya dan melindungi masyarakat.

\section{Daftar Pustaka}

Ahmad Hanapi, 1993, Asas-asas Hukum pidana Islam, Bulan Bintang, Jakarta

Andi Hamzah, 1986, Kamus Hukum, Gramedia

Abdul Qadir Audah, Muqaranan Bi AlQanuni Wadh'i, Makhtabah Dar Al-Arubah, Kairo

Abdul Wahab Khalaf, Khulashah AlTarikh Al-Islami Al-Majlis Al-'Ala Al-Indunisi Lida'Wah Al-Islamiyah, Jakarta

C.S.T. Kansil, 2009, Tindak Pidana Dalam Undang-undang Nasional, Jala Permata Aksara, Jakarta

Djoko Prakoso dan Nurwachid, 1983, Studi Tentang Pendapat-Pendapat Mengenai Efektifitas Pidana Mati Di Indonesia Dewasa Ini, Ghalia Indonesia, Jakarta

Kiblat, Dalam Hukuman Mati Ada Kehidupan, No. 19 Tahun Ke XXVI, Febuari

Dede Rosyada, 1992, Hukum Islam Dan Pranata Sosial, Lembaga Study Islam dan Kemasyarakatan, Jakarta

Departemen Agama RI, 2002, Mushaf Al-Qur'an terjemah, yayasan 
Komunike, Volume XI, No. 1, Juni 2019

penyelanggaraan penerjemah AQur'an, Jakarta

H.A. Dardiri, Humaniora, 1986, Filsafat dan Logika, Rajawali, Jakarta

M.Yunan Nasution,1980,Hukuman

Mati Menurut Ajaran Islam, suara masjid, No.67, April

Mahmudi, 1980, Tentang Pidana mati, harian kompas

Muhammad Abu Zahrah, Al-Jarimah Wa Al-'Uqubah Fi Al-Fiqh Al- Islam, Makhtabah Al-Angelo AlMishriyah, Kairo

M. Abdul Mujieb, 1994, Kamus Istilah fiqih, Pustaka Firdaus, Jakarta

M. Karyadi, Komisaris Besar polisi PNWN, Himpunan Undang-undang Terpenting Bagi penegak Hukum, Politeia, Bogor

Mahmud Syaltut, 1996, Al-Islam Al'Aqidah Wa Syari'ah, Dar AlQalam, Mesir
R.soesilo, 1979, Pokok-pokok Hukum Pidana Peraturan Umum dan Delik-delik Khusus, Politea, Bogor

R. Sugandhi, 1980, KUHP dan penjelasannya, Usaha Nasional, Surabaya

Roesla Saleh, 1978, Masalah Pidana

Mati, Aksara Baru, Jakarta

S. Margono, 2005, Metodologi Penelitian Pendidikan, PT. Asdi Mahasatya, Jakarta

Sayyid sabiq, Fiqh Al-Sunnah, Dar AlFikr, Beirut

Suharto RM, 2002, Hukum Pidana Materiil Unsur-Unsur Obyektif Sebagai Dasar Dakwaan, Sinar Grafika, Jakarta

Topo Santoso, 2000, Menggagas Hukum Pidana Islam, Al-Syamil, Bandung

Yan Pramadya Puspa, 1977, Kamus Hukum Bahasa Belanda, Indonesia Dan Inggris, Aneka Ilmu, Semaran 